\title{
The Diaolou of Kaiping (1842-1937)
}

Buildings for dangerous times

\section{Patricia R.S. Batto}

\section{(2) OpenEdition}

\section{Journals}

Electronic version

URL: http://journals.openedition.org/chinaperspectives/1033

DOI: 10.4000/chinaperspectives. 1033

ISSN: 1996-4617

\section{Publisher}

Centre d'étude français sur la Chine contemporaine

\section{Printed version}

Date of publication: 1 July 2006

ISSN: 2070-3449

\section{Electronic reference}

Patricia R.S. Batto, « The Diaolou of Kaiping (1842-1937) », China Perspectives [Online], 66 | July- August 2006, Online since 01 June 2007, connection on 28 October 2019. URL : http://

journals.openedition.org/chinaperspectives/1033 ; DOI : 10.4000/chinaperspectives.1033

This text was automatically generated on 28 October 2019 .

(c) All rights reserved 


\title{
The Diaolou of Kaiping (1842-1937)
}

\author{
Buildings for dangerous times
}

\author{
Patricia R.S. Batto
}

\section{EDITOR'S NOTE}

Translated from the French original by Jonathan Hall

I would particularly like to thank Annie Au-Yeung for her valuable help in preparing this article.

1 To the west of the Pearl River Delta, in villages nestling amid green bamboo and banana groves and surrounded by a patchwork of rice paddies, stand a number of incongruous dark towers bristling with battlements, fearsome fortresses full of arrow slits, and even the occasional elegant turret above an ornate mansion. All these buildings, in the middle of the Chinese countryside, look like faint reflections of a distant West. How did they end up on the banks of the Kaiping rice paddies?

2 Kaiping is situated in south-western Guangdong and, according to official figures, has 1,833 of these buildings or diaolou ${ }^{1}$, most of which were built in the early twentieth century. But the local authorities have only listed those in a good state of repair, hoping to get some of them included among the Unesco world heritage sites ${ }^{2}$. Though long neglected, they are now a major asset in promoting tourism and a factor in the competition between Chinese cities to attract visitors. Their value is enhanced by the fact that the visitors being targeted are overseas Chinese (Huaqiao) who have been the objects of solicitation by Beijing since China's opening in 1979.

3 Kaiping, along with the other neighbouring xian (sub-prefectures or districts), Taishan, Xinhui and Enping ${ }^{3}$, was one of the centres of Chinese emigration in the nineteenth and twentieth centuries to south-east Asia and North America (the United States and Canada). The xian was set up in 1649, under the Qing dynasty, with Cangcheng as its district capital. In 1952, the government of the xian was installed in the township of Sanbu, and in 1993 Kaiping became a municipality (shi). There were 680,000 inhabitants in Kaiping in 2003 for an area of 1,659 square kilometres, of whom 240,000 belonged to 
the urban area itself (the township of Sanbu), and the others among the remaining 17 townships and 2,800 villages and hamlets ${ }^{4}$.

In this article I will be concerned with the peculiarities of the diaolou architecture, in terms of both the materials and the techniques used in their construction. To my knowledge, there is no work in any Western language specific to the diaolou, even though these strange buildings are mentioned in passing by some works on the region ${ }^{5}$. Publications in Chinese are all recent, and fairly scarce ${ }^{6}$, so many questions about the diaolou remain unanswered. In order to explain the purpose of these buildings, I have made a selection from among the fifty or so accounts published in a collection by the Kaiping municipality in $2001^{7}$. I have made the selection on the basis of their representative character of the political and socio-economic conditions in the region before 1937, thus helping us to understand why the diaolou were built and flourished within this geographically limited area in the early years of the twentieth century. I have also relied on local monographs, including the most recent published in 2002 and one previous compiled in 1932, before the Communist Party came to power. Gaps in my information were filled through interviews with local officials during my stays in Kaiping in 2005 and 2006, when I visited many villages, particularly those containing the diaolou mentioned in my selected accounts.

The geographical situation

5 Western Guangdong consists of broken terrain, and Kaiping is surrounded by hills to the north, west and south ${ }^{9}$. However, at a time when most transport and communications were by river, Kaiping was better endowed than certain neighbouring xian, since its land was traversed by the Tan River linking Kaiping to the town of Jiangmen, and to the whole of the Pearl River Delta beyond. Only a third of its land is arable $^{10}$, and most of that stretches along the Tan River and its tributaries. From the late eighteenth century onwards, demographic pressure increased enormously, and despite a twice-yearly rice harvest the land could no longer sustain the whole population ${ }^{11}$. 


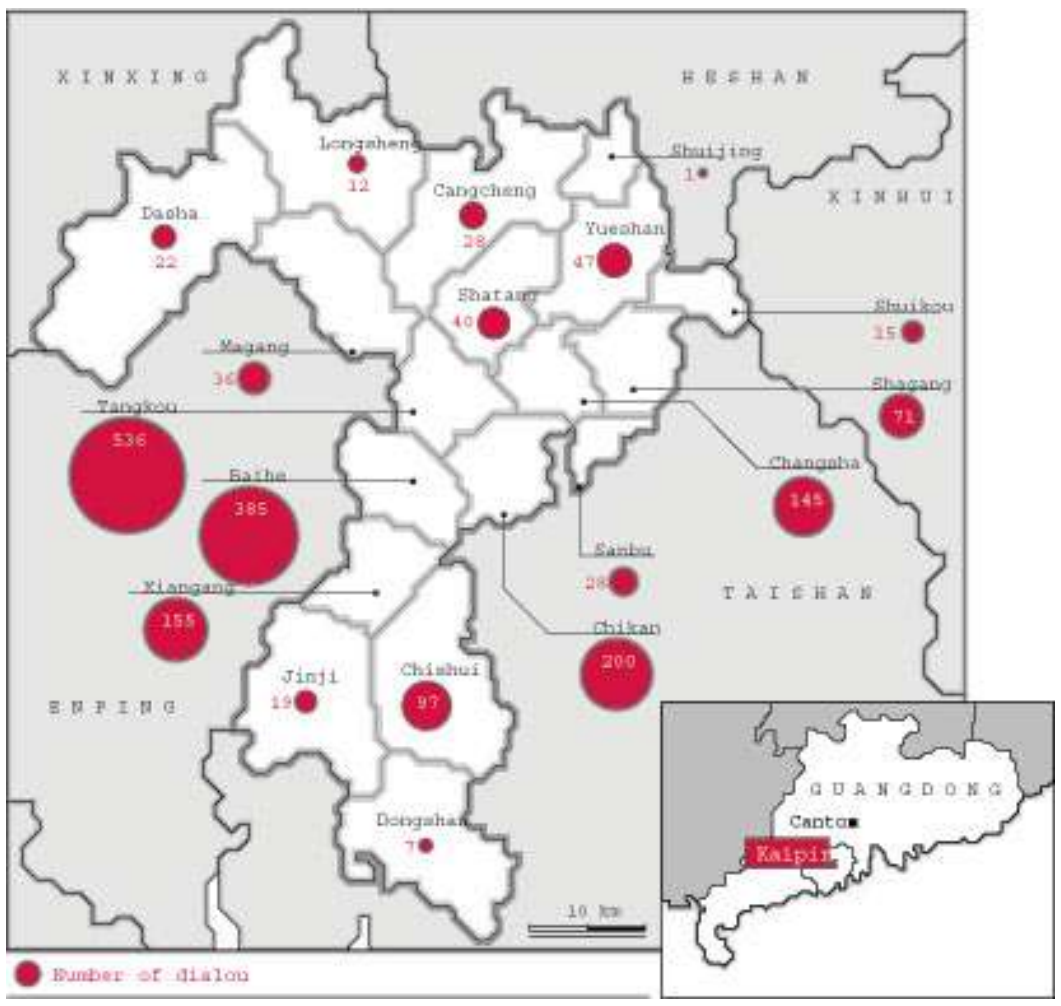

The lineage system

On the eve of the agrarian reforms following the Communist victory in $1949,42.6 \%$ of the cultivated land in Kaiping was communally owned ${ }^{12}$. At that time, the social system depended on lineal descent ${ }^{13}$. Based on the principle of male descent, the clan lineages included people of very different social standing-rich and poor, weak and powerfulall claiming descent from a common ancestor, to whom homage was regularly paid. In Kaiping, the lineages were locally based, linking the principle of common descent to that of a shared locality. The members of the same lineage lived in the same geographic area, which allowed both the collective celebration of ancestral cults and the establishment of social and economic ties. Most of the villages and hamlets in Kaiping are based around a single lineage, and their male inhabitants all have the same surname ${ }^{14}$. The social and economic importance of the lineages is backed by their ownership of property, particularly the lands held in the name of the ancestral temples.

The lineage structure also compensates for the weakness of the local administration. In general, the villagers have little direct contact with the state, and consider its representatives as predators, since their main role consists in levying taxes and organising conscriptions. The military garrisons in the xian are there to check any antigovernment revolts, rather than to protect the life and property of individuals.

The historical context

The inhabitants of Kaiping built the diaolou in their villages during a time of chaos. Just like the medieval castles in Europe and other such fortresses, they had a defensive purpose. In 1842, following the first Opium War the Treaty of Nanking ended Guangzhou's monopoly on trade between China and the West, opened up five ports including Shanghai, and ceded Hong Kong to the British. From 1851 to 1864 the Taiping 
rebellion set southern China ablaze, leading to the deaths of 30-40 million people. Guangdong province was ravaged from 1854 to 1856, firstly by the revolt of the Red Turbans who besieged Guangzhou at the end of July 1854, and then by the subsequent repression ${ }^{15}$. Following that, war broke out between the Punti and the Hakka peoples from 1856 to 1867 , leading to hundreds of thousands of deaths ${ }^{16}$. The Chinese Republic took over from the Empire in 1911, but the general situation remained precarious; between 1916 and 1926 the country was torn apart by the struggles between the warlords.

In the years between the end of the nineteenth and the early twentieth centuries, the Kaiping region was very unstable ${ }^{17}$. According to written local monograph accounts, between 1912 and 1930 there were reports of more than a hundred murders, over a thousand abductions, and 71 major robberies, in addition to the countless thefts of buffalo and other goods. Cangcheng, the capital of the xian surrounded by ramparts was taken by assault on three separate occasions by bandits, who kidnapped the sub-prefect during one of their attacks. In addition, between 1912 and 1926, eight schools were attacked, leading to the abduction of over a hundred pupils and teachers.

The origin of the diaolou and their various types

10 The building of the diaolou started very early in Kaiping. The 1932 monograph from the xian mentions the Fengfulou ("Respectful gift to my father") erected at the beginning of the Qing dynasty ${ }^{18}$. It relates that during the Kangxi era (1662-1723), Xu Longsuo, a native of the village of Longtian, near the township of Yueshan, distinguished himself by his aptitude for study at the school in the local capital, Cangcheng. He took the official examinations but was not successful, so he became a merchant. His father chose the daughter of one of his friends to be his son's wife, and she gave birth to a son. On reaching the age of fifty, Xu Longsuo retired from his now flourishing business which he handed over to his son. One evening, his wife did not come home. They learned that she had been abducted upon receiving a ransom demand from her abductors. Her son sold their land and their most precious possessions, and sought the aid of their relatives and friends to raise the money. He was preparing to hand the money over when a young boy arrived, bearing a message from the abducted mother. "It is useless to ransom me", said the message in effect, "I have decided to resist at the cost of my life. The money you have gathered should be used on a building to provide security for your father". The young messenger's mother had also been abducted, and was locked up with Xu Longsuo's wife. The latter, knowing that her companion was about to be released upon payment of the ransom, had entrusted her with sending the message. Then she killed herself by jumping off a cliff. In accordance with the final wish of his mother, her son had a four-storey granite building made, and named it "Respectful gift to my father".

11 Of course, this tale of the deeds of both a virtuous wife and a son imbued with filial piety, is too exemplary in the Confucian spirit to be taken literally. Still, its inclusion by officials among the local monograph shows that banditry, abductions, local government laxity over public safety and the consequent measures for self-defence by the population, all go back to long before the Opium War.

12 Nowadays, the oldest extant diaolou in Kaiping is the Yinglonglou ${ }^{19}$ in the village of Sanmen (Chikan township). It was built by the Guan lineage during the Jiajing era of the Ming dynasty (1522-1566). It is a massive extended fortress in marked contrast with the diaolou constructions of a later date, which are mostly high towers. The Yinglonglou is a 
rectangular building made of large red bricks, with a turret on each corner. Its walls are 93 centimetres thick, covering an area of 152 square metres, and its beams and floors are of wood. It was renovated in 1919, and during this final stage, it was rebuilt with grey bricks (qingzhuan) and stood at 11.4 metres in height, including a ground floor and two upper storeys. The roofs were completely rebuilt, and the original wooden doors and shutters were replaced with iron ones.

The materials used for the construction of the diaolou play a determining role in their architectural design. Several types can be found ${ }^{20}$, depending on whether they are made of stones, rammed earth, grey brick, or cement and steel. The use of stones and rammed earth is characteristic of the oldest type, even though these materials might well be used later, mainly for reasons of economy. The use of reinforced concrete comes at a later date, since it requires cement and steel, which are imported and therefore expensive materials.

The stone diaolou. These buildings are generally straightforward towers consisting of one or two storeys. The walls are about thirty centimetres thick. About ten of them are still extant in the hills north-west of Kaiping, near the Dasha township.

The rammed earth diaolou (nilou). This category includes buildings made of crude bricks (adobe) as well as those actually made of pounded clay or rammed earth. In building the former, sun-dried pounded earth bricks were used. The walls were often coated on the outside with a layer of chalk mixed with sand or a layer of cement, for waterproofing and weather resistance. In the latter case, the basic material was earth mixed according to a formula with fine sand, chalk, and unrefined sugar or glutinous rice, which were pounded between two large wooden planks. This kind of construction took a lot of time to complete. To make it more viscous, the earth was soaked for a long time, sometimes for up to a year, during which it had to be stirred constantly to prevent it hardening. The other ingredients were only added when it was about to be used. Walls of rammed earth measuring thirty to forty centimetres thick have a strength comparable to reinforced concrete. These diaolou usually have three storeys, but they may have up to five if they are built using solid materials, such as steel girders. There are about a hundred extant examples, mostly near the townships of Chishui and Longsheng.

The grey brick diaolou (qingzhuan lou). Grey bricks were commonly used at the end of the Qing dynasty, and had great aesthetic appeal ${ }^{21}$. The walls of the diaolou built in brick were forty to fifty centimetres thick because brick is not as strong as rammed earth but is well suited to the humid climate of the region. Some diaolou are built entirely of grey brick, while others have grey brick on the outside and rammed earth on the inside ${ }^{22}$.

Like the diaolou built of stones or rammed earth, the grey brick ones generally have two or three storeys, but their design is less simple. They have towers, or "swallow's nests" (yanzi wo) jutting out sideways on their roof, and they are more ornate. Out of the 1,833 diaolou in the municipal inventory, 249 are made of grey brick. They are very numerous in the Yueshan region, north-west of Kaiping. The beams, floors, and staircases of all the above three types were usually of wood, so nearly all have suffered damage, and often only the empty walls remain ${ }^{23}$.

18 The reinforced concrete diaolou (gangjin shuini lou). These are the most widespread, the most ornate, and the best preserved. Out of the 1,833 recorded by the municipality, $1,474(80 \%)$ are made of concrete. They were built in the closing years of the Empire and under the Nationalist regime before the Sino-Japanese war (1937-1945), with a 
major wave of building from 1920 to 1930. The construction materials were Portland Cement $^{24}$, sand, gravel ${ }^{25}$, and steel. The walls are only forty centimetres thick but, owing to the materials used and the progress in building techniques, these diaolou are taller than the preceding three kinds, often having four or five storeys. The tallest of them, the Ruishilou has nine storeys. As in the case of the other types, the doors, window bars, and shutters are made of iron. However, the beams, floors and staircases are no longer made of wood, but of steel and concrete ${ }^{26}$.

The reinforced concrete diaolou have a more complex layout. Their windows allow increased air and light, being more numerous and larger than those of the preceding type, some of which have only arrow slits as openings. Also, the window embrasures and lintels are highly decorated. The biggest change is in the upper sections of these buildings, which are overhanging and more ornate. This is a development which provides for better defence while also improving the aesthetic appearance. At the top of the building, the turrets known as "swallow's nests" overlooking its sides, or the covered galleries running all the way round, usually have openings in the floor. These allow the defenders to be right above any potential assailants, while remaining protected from them. The material used was a determining factor in this new architectural form. Reinforced concrete allows for the construction of unsupported extensions, cupola roofs, domes, and other rounded shapes.

The steel and cement, imported from the outset along with the technology for building in concrete, were brought back from abroad by the emigrants from Kaiping. Overseas emigration also changed local people's aesthetic tastes, giving rise to a peculiar combination of Chinese and Western architectural features, such as the typical domes, Greek columns, and decorative elements like acanthus leaves. Most extant examples are made of reinforced concrete, and they date back to the end of the Empire and the early days of the Republic, because before the inhabitants of Kaiping emigrated, only a handful of rich people could build what they wanted ${ }^{27}$. It was overseas emigration, coinciding historically with the invention of reinforced concrete, which made the building of the diaolou possible.

Emigration as a determining factor

21 Kaiping is one of Guangdong province's qiaoxiang, a place of overseas emigration, in which the money remitted from abroad is a major economic resource ${ }^{28}$. According to the statistics for 1957, the Huaqiao who had returned to the country after working abroad together with their dependents amounted to over $10 \%$ of the population of Kaiping ${ }^{29}$.

From the end of the eighteenth century, the inhabitants of Kaiping began to migrate to other parts of China, driven by demographic pressures. By the late nineteenth century they were emigrating overseas, mainly to Southeast Asia, North America (the United States and Canada), and Australia ${ }^{30}$. The first waves of emigration to North America were spread out between 1849 and 1880. At first the emigrants took part in the California Gold Rush, and were called jinshanke (kam-shaan hak in Cantonese, i.e. "guests of the gold mountain") ${ }^{31}$. Later they took part in building the railways of North America, in the USA from 1860 to 1880, and in Canada from 1880 to 1884. At the same time, the Western powers were beginning to exploit the plantations and mines of Southeast Asia, for which they recruited mainly Chinese labourers ${ }^{32}$. According to the local monographs ${ }^{33}$, the first emigrants from Kaiping included people fleeing the Red 
Turban revolt (1854-1856), followed by Red Turbans fleeing from the subsequent repression.

In July 1854, some members of the Kaiping secret societies (Tiandihui or Triads), aided by 1,000 men from the secret societies of Heshan, seized Cangcheng, the capital of the xian. The sub-prefect and his adjutants committed suicide, and their families were hanged. The Red Turbans opened the town granaries and distributed the grain. When the authorities managed to regain control, 400 people were executed, mostly by drowning in baskets thrown into the Tan River.

To put an end to the Red Turbans, the local elite had raised armed militias. But when the revolt was repressed, traditional hostilities between the Punti and the Hakka flared up again, with increased force since both camps were now fully armed. There began a murderous ten-year conflict, which the Punti finally won. The Hakka were obliged to flee from their land, which passed into the hands of the Punti, and it remained part of the communally owned land up to 1949. The conflict between the Punti and the Hakka also added to overseas emigration. In addition to those who emigrated voluntarily were those captured by the opposing camp, to be sold as coolies, just like some of the people abducted by bandits.

But most of those emigrating from Kaiping did so for economic reasons. Emigration was not uniformly spread throughout the territory of the xian. It mostly affected those lineages settled in the densely populated areas, like the middle and lower reaches of the Tan River, particularly the Zhang, the Xie, the Zhou, the Fang, the Guan, and the Situ. The emigrants often came from the same village-since emigration operated through family contacts-and therefore had the same surname ${ }^{34}$. Once they were abroad, those that were not recruited for the railways, mines or plantations either worked in laundries or restaurants or else opened small shops or stalls. Mostly, their ambition was to return to their village after making their fortune, get married and have sons, buy some land and build a house on it, and then set up a shop in a neighbouring township. As many countries were quick to enact discriminatory antiChinese legislation, forbidding the arrival of fresh immigrants-preventing families from re-uniting-and denying citizenship to those already there, many emigrants opted to return home rather than remain in such a hostile environment ${ }^{35}$. When they returned home, they often enjoyed a high degree of social prestige.

When they first set out, the vast majority of the emigrants were young men under twenty years old. At that time, marriages in China were arranged by the parents who usually found them a wife back home. Sometimes the future husband was consulted, but he only attended the marriage ceremony if he had the means to return ${ }^{36}$. The emigrants' wives took care of their parents-in-law, in accordance with tradition, but they also had to do agricultural tasks, including the most burdensome, since the men were absent. They lived like widows, leading a solitary existence. Their husbands only came back every eight, ten or even fifteen years. The infrequent births marking these occasional returns led to a situation where brothers belonged to different generations. Another consequence was the frequent practice of adopting boys ${ }^{37}$. Both situations led to quarrels, particularly in the sharing of inheritances ${ }^{38}$.

Wealth and luck

Estimates of the proportion of the minority of emigrants who did grow rich vary widely, from $5 \%$ to $20 \%{ }^{39}$. In the early twentieth century, among these families it was considered proper to display a degree of Westernisation ${ }^{40}$. Western-style clothes were 
worn (not locally woven ones) as were leather shoes (not cloth ones). Meals were served with knives and forks (not chopsticks). Marriages were celebrated with great pomp; daughters were richly endowed, and the bride price for daughters-in-law was high. Certain Anglicisms entered the local dialect: gei (ji in Mandarin) was "cake", suoli (shuli in Mandarin) was "sorry", feixi (feishi in Mandarin) was "face", etc. Returning emigrants smoked imported cigarettes, took to opium, and frequented gambling and pleasure houses. The richest built Western-style villas (yanglou) were in the new villages, which were often situated alongside their former family village.

The diaolou in Kaiping are not uniformly distributed (See map). They are concentrated around the townships of Tangkou, Baihe, Chikan, Xiangang and Changsha. They are most numerous around the centres of emigration, since the financial support of the emigrants was essential to their existence. In the early twentieth century, Chikan, Changsha, and Shuikou were the principal market towns of the xian, controlled by Cangcheng. According to the 1932 monograph, the township of Chikan, divided between two lineages, the Guan and the Situ, was the most prosperous ${ }^{41}$. The mail and remittances sent from abroad by the emigrants arrived in townships where there were institutions like post offices and banks. The remittances were generally addressed to shops, whose owners were known to the banks and able to handle the orders. These traders then forwarded the money and the letters to their recipients, charging a small fee. Since the villagers often only came to the towns on market days, the town's traders served as a link between the villages-particularly those belonging to their own lineage -and the outer world.

The emigrants were regularly asked for economic support for their village or their lineage's activities. Money from emigrants anxious to ensure the security of their families left back home, was used to build the diaolou. Some of these were built by a single family, providing its members with living quarters (julou). Buildings of this sort were equipped with amenities such as a kitchen and toilets. Others were built by several families, or by all the families of a village who contributed to it (zhonglou). In this type, each family would normally be given a small room, to store their most precious belongings and to use as a refuge in case of danger ${ }^{42}$. Finally, some diaolou were built on the joint initiative of several neighbouring villages, which usually belonged to the same lineage. These served as watchtowers (genglou) and were mostly situated outside the villages, on top of a small promontory or in some other strategic location. One quarter of the 1,833 diaolou on the municipal register are buildings which were constructed by a village community, and if the watch towers are added, the number of communal buildings rises to over a third. The diaolou displayed the riches of a village, and its degree of social cohesion in the case of communally owned ones; they gave the village some prestige. By this means, villages and lineages showed their power, hoping to avoid confrontation or provocative challenges from neighbours within the overall situation of fierce rivalry over scarce resources.

When the money required for building a diaolou was gathered, a feast day was chosen for laying the foundations, which consisted of enormous wooden stakes driven into the ground with huge hammers ${ }^{43}$. Next, a large bamboo shelter was raised over the wooden stakes, to cover the whole area of the future building and to protect it against the weather. The construction was entrusted to teams of twenty or thirty people, under the direction of master masons (nishuijiang) who were usually native to the region. Most of the time, there was no architect, in the proper sense. Sometimes the diaolou were built 
according to plans drawn up by the landowner or inspired by images, such as postcards, brought back from abroad; on other occasions, the overseers (nishuijiang) just followed the instructions they were given.

Naming the diaolou

31 A very important element of these buildings was their name, written in calligraphy high up on the main façade when it was completed ${ }^{44}$. As in the case of the inscriptions on the ancestral temples, whenever possible a well known calligrapher was approached in order to confirm its prestige. The Ruishilou, which was the highest diaolou in Kaiping, situated in the village of Jinjiangli near the township of Xiangang, was built by Huang Bixiu, a rich merchant who, together with his two sons, owned a medicine shop and a bank (qianzhuang) in Hong Kong. He wished to provide protection for his parents and wife in the village, and spent HK\$30,000 on building it, in a process which took three years, from 1921 to 1923. The plans were drawn up by one of his nephews. The calligraphy proclaiming its name on the sixth storey was a present from the abbot of the Six Banyans Temple in Guangzhou, who was a celebrated calligrapher and friend of Huang Bixiu ${ }^{45}$. Diaolou which were built by individuals, usually bore the first name or honorific title (hao) of the owner. For example, Huang Bixiu's hao was Ruishi. The completion of the Ruishilou coincided with the $80^{\text {th }}$ anniversaries of Huang's mother and father, so he celebrated this auspicious event with a five-day banquet. The entire neighbourhood was invited and even people just passing through were invited to take part. These festivities cost him about HK\$10,000.

In order to reinforce the riches and power of the village or lineage, the communally built diaolou were often named after the village, location, or lineage chief. Otherwise they might be given a title reflecting the qualities attributed to the building (for example: ju'anlou, or tranquil dwelling). By tradition, once a diaolou was completed, its name was either sculpted out of lime, or moulded out of lime and then attached. Alongside the characters there were usually a number of motifs to bring good luck. There are very few diaolou without a name. But there is one to be found in the village of Xihe, near the township of Baihe, which is the subject of the following story ${ }^{46}$. In the 1920s and 1930s, many of the inhabitants of Baihe left to find work in the United States, Canada, Mexico and Cuba. One young man, Fang Fuxin, set out for the United States together with some relatives before he was twenty. He worked in laundries and restaurants, sending money back regularly to support his parents and pay for the education of his two younger brothers. In 1931, he reached the age of 20 , which meant that he must become established and get married. His parents searched for a wife for him in his home region. They found a ravishing young girl called Meiyu and sent him her photograph. On seeing her picture, Fang Fuxin was very happy and agreed to take her as his wife. But he was unable to return for the marriage ceremony in person, because travelling was expensive and inconvenient. He sent some money to enable his relatives and friends to gather for a banquet and celebrate the happy occasion. So Meiyu became Fuxin's wife and moved in with her husband's family.

Fang Fuxin's family lived in a house consisting only of a shared living room with its ancestral altar, and two bedrooms. The first was occupied by his parents, and the second by the three brothers. After her marriage, Fuxin's wife took over this second bedroom, and the two younger brothers moved into a space in the living room separated off by a wooden partition. But as the two brothers grew older, matchmakers appeared proposing some marriageable young women as wives. The problem of living 
space became urgent. So Fang Fuxin then sent all his savings, asking his father to build a house with them. Diaolou were fashionable in Kaiping, and someone had already built one at the back of the village. Fang Xiuwen, Fuxin's father, chose a site behind the village, and in six months a diaolou of two and a half storeys was completed. According to custom, the father asked the master masons to inscribe its name on the façade. He decided to call it Xiuwenlou, using his own name.

Meiyu was happy to see it finished, but was far from happy to see it named after her father-in-law. She believed that, as it was her husband's money which had enabled it to be built, it ought to be called Fuxinlou after her husband. She was afraid that using her father-in-law's name might mean that he had built it, so the diaolou would belong to the whole family. Also, her two brothers-in-law could move in, and they might even start a dispute with her to claim ownership. She complained to her father-in-law, but the discussion turned into a quarrel. From Fang Xiuwen's point of view, the money for the building was sent by a son whom he had raised, so it was normal for him to put his own name on it. Since it gave him prestige and was a matter of face, he refused to change its name. His wife, Fuxin's two brothers, and the village elders all took his side. But Meiyu did not give up so easily. The next day she went up inside the diaolou and threw down the three characters of its name. When this was reported to her father-in-law, he wanted to restore his loss of face and got the master masons to return to put the three characters back. But Meiyu refused to let them in, thus making her father-in-law's loss of face complete. The quarrel grew more poisonous, and no-one managed to dissuade Meiyu. Finally she moved into the diaolou alone.

Both camps appealed to Fang Fuxin, over in the United States. In the end he raised enough money to construct a grey-brick residence, while Meiyu continued to live alone in the diaolou. Finally, thanks to the mediation of relatives and other people in the village, the two sides seem to have become reconciled. But to this day the building is known as the "diaolou without characters" (Wuzilou).

The importance of Hong Kong

The money from the emigrants-including those from Kaiping-was remitted via Hong Kong, the place through which both men and merchandise passed as they moved between China and the rest of the world ${ }^{47}$. The case of Guan Huade gives a concrete example of how this took place. He had left Kaiping for Canada under the Qing dynasty, and at the age of 38 he returned to get married. Two years later, he left again for Canada, where he opened a small shop which sold medicines and other merchandise. In 1924, now aged 58, he returned to Kaiping and opened a medicine shop in the township of Chikan, where he handled letters and money orders from emigrants abroad. He was also the owner of a lodging house in Hong Kong, managed by one of his sons. It received departing emigrants, and overseas Chinese from Canada and the United States returning to visit their families in China. Guan lineage members living overseas often entrusted money orders, and even currency, to people returning to China, requesting them to deposit them at the lodging house. From Hong Kong, this mail and money was transferred to the medicine shop in Chikan by a nephew of Guan Haide as he shuttled between the two places. He was one of the many marine couriers (xunyangma, or shuike $)^{48}$ of the time. Many of the finest buildings in Kaiping-for example the villas and the diaolou in Xiacun near Chikan, the Ruishilou near Xiangang, and the Rishenglou in Chishui-were constructed by local bankers, which goes to show-should anyone doubt 
it-that even then financial dealing offered a more reliable road to riches than working as a coolie.

One of the sources of Western aesthetic influence on the diaolou appears to have been the colonial buildings in Hong Kong, through which the emigrants had to pass on their outward and inward journeys, and more generally, those of the British Empire as a whole, from Scottish mansions to Mogul India. Other elements were picked up by the emigrants in the various countries where they worked. There were probably some sorts of catalogue, particularly for decorative features, because certain motifs recur from one diaolou to another, such as window frame adornments. But until now, no design plan or catalogue has been discovered. All such publications seem to have been destroyed during the Cultural Revolution (1966-1976) ${ }^{49}$. A certain Western flavour would have been spread by them, some of which moreover were certainly sent back from abroad by the emigrants. During the Cultural Revolution, which marked a high point in the rejection of the West, members of emigrant families were often labelled "spies", "traitors", and "counter-revolutionaries". But relations between the emigrants' families and the Communist authorities had worsened well before then, for they were already bad in the aftermath of the Agrarian Reform of the early 1950s. So it is quite conceivable that only a handful not destroyed earlier actually remained to be destroyed under the Cultural Revolution ${ }^{50}$. The reform policies and the opening up in 1979 mark a turning point. From then on, the authorities took a benevolent approach towards emigrants and their families, even going so far as to court their favour.

Building for defence against a sea of troubles

Paradoxically, the money from the emigrants used to organise the defence of the villages, also attracted bandits. According to a local saying, "walking behind every emigrant, there are three bandits" ${ }^{51}$. The acts of banditry aimed at emigrants thought to be rich were looting and kidnapping. Ironically, if a family did not settle the ransom demand, the bandits could always sell their hostages to recruiting agents for labour overseas.

The hostage-taking from the college in Chikan

In December 1922, over two hundred bandits from Tutang, near Magang, attacked the Chikan secondary school ${ }^{52}$. Some of them seem to have entered the town unnoticed in the morning and spent the day gorging themselves. At night, they slipped into the school dormitory and kidnapped twenty-three pupils as well as the headmaster, after which they set out for their hideout with their hostages. They were hoping for substantial ransoms, since the school's teachers and pupils were believed to be from rich families ${ }^{53}$. The trail link between Chikan and Tutan passes close to Yingcun, a village from which several inhabitants had emigrated to the United States. The latter had paid for a diaolou, the Hongyilou, to protect their families. At nightfall, men and women, old and young alike, used to take refuge there to sleep, only returning to their houses at dawn. The emigrants from Yingcun had also provided their diaolou with some useful equipment brought back from the United States, namely an electric generator, a searchlight, alarms, guns and ammunition. Every night men would keep watch from the top of the building, because bandits preferred to attack at night. The absence of electricity and street lighting meant that the villages were immersed in darkness.

That night in December 1922 there was a storm. Suddenly, the men on watch on the Hongyilou saw faint outlines moving furtively in the night. They turned on the searchlight and set off the alarm. The wailing of the alarm bellowing out over the night, 
and the searchlight beam sweeping the countryside before locating its object, took the bandits completely by surprise. They panicked, while from the top of the diaolou, the sentries opened fire. They managed to make out the difference between the hostages and their captors because, to protect themselves from the rain, the bandits were wearing waterproof capes made of palm leaves (suoyi) and broad bamboo hats (limao) ${ }^{54}$. Several bandits were wounded, while others took to their heels. The hostages took advantage of the situation to flee as well. The men from the diaolou and the village militia who had been alerted, took off in pursuit of the bandits. They captured 12 of them, including a leader, and saved 17 pupils and the headmaster. The whole affair attracted great attention, and led to the building of many diaolou, including diaolou schools with classrooms and dormitories to protect teachers and pupils ${ }^{55}$.

41 At first, the villagers only had crude weapons in their diaolou for defence against possible assailants. These included large stones and other projectiles, quicklime, and water with caustic soda which, when the enemy were in range, they squirted through hoses, aiming for their eyes. To frighten off the bandits, they sometimes used firecrackers, but in some places they had guns, and even home-made cannon which they stuffed with gunpowder and bits and pieces like damaged ploughshares. Gradually, thanks to the emigrants, the weaponry became more sophisticated, and some villages had a veritable arsenal of artillery. Traditionally, at the approach of danger, the alarm was raised in the villages with bells and gongs, but these were now replaced with imported sirens. In addition, searchlights connected to a generator gave the villagers a certain advantage, since they could clearly see their attackers while the latter were blinded. Finally, every village traditionally had a team of paid night watchmen (gengfu), to guard the crops in addition to wider duties like preventing theft, maintaining order and guarding against bandits. Now, thanks to the money from the emigrants, some villages and lineages maintained self-defence organisations that were virtually militia units, sometimes even trained or led by martial arts experts or army officers.

But although the implementation of all these measures may have protected this or that village, it did not put an end to the banditry which infested the area. The inhabitants of Kaiping divided the bandits into three different sorts. Firstly, there were the waterborne pirates (haikou). The main effect of the presence of the British navy in Chinese coastal waters after the First Opium War had been to push the pirates back up the rivers towards the interior, while the rivers themselves were the scene for smuggling opium and salt. Secondly, there were the open-country bandits (, tukou) who either sheltered in the forests and hills or lived in villages. The latter were peasants by day and bandits by night. Thirdly, there were mobile gangs from neighbouring xian who made raids into Kaiping (liukou).

The bandits hiding in the hills were demobbed soldiers, former coolies, peddlers, itinerant artisans, unemployed boatmen, banished villagers, and poor peasants, in short anyone who had not managed to find another means of subsistence. These town and country outcasts were also typical members of the secret societies. While bandit gangs often included demobbed soldiers in their midst, conversely it was also common to find former bandits serving in the army or working as mercenaries. In actual fact, the dividing line between soldier and bandit was extremely permeable. With a slight shift in established power relations, an armed band could become either a legal militia or an illegal one, that is to say, a gang of bandits. 

from Kaiping. According to local recorded accounts, both were originally leaders of the minjun (people's army units) at the time of the Empire. These peasant militias operating without a unified command were at the forefront of anti-Qing activities under the leadership of Sun Yat-sen's partisans ${ }^{56}$. When the uprising on October $10^{\text {th }} 1911$ in Wuchang (Hubei) was successful, these minjun came out into the open. A month after the Wuchang uprising, Wu Shen attacked the capital of Kaiping, Cangcheng, causing the sub-prefect to flee to Hong Kong. So it was Wu Shen who caused the Empire to fall in Kaiping. Following this, the provincial authorities gave him charge of the military affairs of the xian. But shortly afterwards, the authorities considered that the mission of the minjun to overthrow the Qing empire was accomplished, and ordered them to be dissolved. Another militia force was set up (mintuan, or "people's regiment"), one of whose tasks was to dismantle the minjun and arrest their leaders. Any minjun unit which resisted became thereby a bandit gang. A few years later, at the time of the Warlords, when the Guangxi army occupied Kaiping, it recruited the leading bandits of the xian, including $\mathrm{Hu} \mathrm{Nan}$, to maintain order, which immediately improved the security situation. But in 1920, the Guangxi army was pushed back by the Guangdong army under the command of Chen Jiongming ${ }^{57}$. Hu Nan, and others like him who had been co-opted by the Guangxi forces, resumed their former activities, and again began attacking villages, stealing, and kidnapping. The security situation worsened again. $\mathrm{Hu}$ Nan fell back to Tutang, and it was he and his men who, among others, were responsible for the attack on the secondary school in Chikan in 1922.

The case of the burnt village

The new villages inhabited by the families of emigrants were among the favourite targets for the bandits, who attacked at night. Sometimes, in order to mark the selected house, an accomplice would leave a lighted joss stick in the incense burner which is attached to the front doors of houses. The reddish glow would guide the attackers in the dark, while the inhabitants, woken by their dogs and hunkered down in their houses, would listen in impotent terror to the looters coming and going through the village alley ways. In June 1928, according to the local monograph dated 1932, there was a bandit attack on the village of Qilongma. They kidnapped 20 people belonging to the Fang lineage, killed over ten people, and set fire to 23 houses $^{58}$. There follows a detailed account of the punitive expedition against the bandit hideout. Money was gathered, and a delegation was sent from Kaiping to the town of Jiangmen to ask the Kuomintang to send troops against the bandits. Five companies of soldiers were dispatched. The expedition ended with the death of over eighty bandits, and five of their hostages, a further ten being freed. The Nationalist army recovered two horses, over fifty rifles, and two machine guns, but five soldiers were killed and 32 wounded. This account, written in 1932, is obviously not very critical of the Kuomintang.

The version put out under the Communist regime is somewhat different ${ }^{59}$. The village of Qilongma was inhabited mostly by emigrants' families belong to the Fang and the Guan lineages. The Fang were in the majority; out of 28 houses and three diaolou, only four houses and one diaolou belonged to the Guan. But originally, Qilongma was part of the Guan lineage's territory. In 1927, some Fang lineage members from the village of Shangtang who had returned after emigrating, together with some of their relatives, organised a committee to build a new village. To do so, they bought some land from the $\mathrm{Wu}$ and from the Guan living near the aforementioned Qilongma. The landowner, Guan

China Perspectives, 66 | July- August 2006 
Heqin received a pay-off of over sixty thousand yuan for this transaction, on the basis that he would guarantee the safety of the Fang during the construction process. Another important member of the Guan lineage, Guan Jiyun nicknamed "king of the xiang" came to hear about it. He had been excluded from the deal and had earned nothing from it, which put him on bad terms with the Fang in Qilongma.

Now, in the village of Qilongma, there were two Guan lineage members. One, called Guan Chaoxiang, had returned from the United States, and the other, Guan Ronggeng, had relatives abroad, and both were also on bad terms with the Fang. Guan Jiyun, the "king of the xiang", took advantage of this situation. He called upon his followers to burn down a small building belonging to them, making sure that they would think that the arsonists were the Fang. The hostility of the Guan began to worry the Fang. Some of them living in Qilongma returned temporarily to their old village, and the others hid during the day so as to avoid the Guan, taking refuge at night in their diaolou. In an attempt to calm the rising tension, four different lineages-the Fang, the Zhou, the Li, and the Xie from the outskirts of Tangkou-sent representatives to see Guan Jiyun. The Fang were prepared to pay him several thousand ounces of silver ${ }^{60}$. But he considered the sum too small and refused it. Not only that, he did a deal with bandits to seize the goods belonging to the Fang in Qilongma.

During this attack on the village, one of the Fang barricaded himself in his house with his mother and pregnant wife, and resisted with his rifle in his hand. The bandits locked the door with a bolt on the outside and set fire to the house. The three inside were burned alive. After sacking the village, the bandits burned another two diaolou and 22 houses belonging to the Fang. They also captured another 21 people, held them at their hideout and demand ransoms.

The Fang lineage resolved to seek justice, and gathered some money together. The Nationalist authorities, "just for show" (yanren ermu) according to this account, sent five companies of soldiers against the bandit hideout. The bandits used their hostages as human shields, and five of the Fang were killed. At the same time an appeal for justice in the courts was launched. The Kuomintang dragged out the business for more than eight months and, according to the reckoning in this version, they profited by extorting over two million yuan from both parties-the Guan, and the Fang from Chikan and Tangkou. Finally, in February 1929, the verdict was pronounced. Guan Chaoxiang from Qilongma, after having spent on his defence more than sixty thousand dollars earned in the United States, was shot. But Guan Jiyun, the "king of the xiang", was not even bothered by the judicial authorities.

Attacking emigrants' villages was a routine affair for the Kaiping bandits. But in this particular case, they were acting as mercenaries in a vendetta (xiedou) between two rival lineages. Such conflicts, which are the outcome of long-standing rivalries between two villages or lineages, may be over material assets (usually water or land), but they can also be over "symbolic" matters, such as geomancy (fengshui) and its rules about the position of family graves in particular, because these are believed to guarantee future prosperity ${ }^{61}$. The Qilongma affair escalated so far that the authorities were called in. The self-interestedness behind their intervention was later denounced in the second of the above versions of the events, although this must be treated with caution since it is imbued with Communist anti-Kuomintang propaganda. The Qilongma affair also reveals the limits to the solidarity within the lineages themselves, for it is an example of how the xiedou were often unleashed by the rich and powerful for their own motives. 
In this instance, a leading lineage member had no hesitation in sacrificing lives, including that of a fellow lineage member, in pursuit of personal gain.

The communal pestle affair

51 In the rivalries between villages and lineages, the diaolou served as a display of power and as a guard against attacks from neighbours. This is illustrated by the story of a diaolou built opposite the village of Shengliang (Sanbu township) to shelter a stone pestle. In this case, the conflict centred on an item of purely "symbolic value". In the 1920 s, at harvest time, the peasants would bring the rice sheaves back to the village to be dried. After the threshing, they used a bamboo grinder to remove the inedible husk from the grain ${ }^{62}$. Next, with the use of a pestle, they polished the rice by removing the outer covering to whiten it. If the grains were then soaked in water and pounded again with a pestle, they broke into pieces which, on being passed through increasingly fine sieves, yielded a flour which could be used to make cakes. Traditionally, these cakes were made and savoured at the Spring Festival (Chinese New Year) and on other important feast days, when they were also presented as offerings to the ancestors. Usually, every family had a grinder and a pestle, and the same cakes were made for funeral ceremonies when an aged member died. But there was a rule that on such occasions you could not pound the rice in your own home.

In 1928, a venerable old gentleman died on New Year's Day. The family had to pound the rice to make the traditional cakes and, as they were not able to do it at home, they had to ask their neighbours to let them use their pestle. But on New Year's Day, people were very reluctant to mix the auspicious with the inauspicious. The deceased's family implored in vain. However much they begged, no-one was willing to lend their pestle. Finally, the family remembered that the neighbouring village of Tangbian had a pestle for common use by its inhabitants. They approached the village chieftain, who was very understanding and allowed them to use it. So they quickly took the soaked rice to the neighbouring village, pounded it, and were able to go ahead with the funeral rites.

This affair aroused much emotion among the elderly in Shengliang. They worried about what would happen if no-one was willing to lend their pestle when they died. Would they be condemned to the wandering existence of hungry ghosts? The elderly villagers called a meeting, whose outcome was the decision that their village should also acquire a communal pestle. They chose a site at the top of Taoniu Hill opposite the village, and waited for a feast day to build a crude bricks (adobe) shelter for the pestle. Some elderly people died and the pestle was used to make the requisite rice flour. Two years passed.

But then in a neighbouring village, a powerful man claimed that the stone pestle and its shelter were bringing him bad luck. He owed the prosperity of his businesses, which made him the richest man in the area, to the protection of his ancestors, and their tomb was built into the Taoniu hillside. The pestle and its shelter on the hilltop, he said, were weighing on the head of his ancestors, bringing him a lot of bad luck.

One day, he gathered some village youths together, shouting and raging that before the Shengliang people had set up their pestle and shelter, everyone's life was free of troubles, but that since then their village had been seriously affected. He incited the young men to go and have it out with the inhabitants of Shengliang, to insist that they demolish the shelter, and pay damages. Several of the youths were fired up by his call, armed themselves with tools, and set off for Shengliang. 
56 A conflict between the two villages could have been sparked at any moment. But someone warned the local authorities, who quickly assembled a few men to intervene and attempt a reconciliation and prevent a full-scale xiedou. News of the affair quickly reached the higher authorities. They sent an official who engaged in a process of patient reconciliation and managed to calm flaring tempers. Finally, the authorities agreed to the inhabitants of shengliang building a shelter, but they argued that the present one was crude and unsafe, and asked them to demolish it and build another.

In 1931, the villagers demolished the old crude bricks shelter. They asked for gifts in money or labour from all their relatives, especially from the emigrants, to build a new one. The first storey of the new shelter was rapidly built. But it was a time of disorder, and the contributions from abroad did not arrive, so building was delayed for two years. In 1933, the money was collected, and the initial plan was altered so that the shelter for the pestle became a three-storey diaolou. As a proof of their riches and social cohesion, the Shengliang villagers felt that it would discourage any future incursions from their neighbours, since the new shelter was without doubt more than capable of withstanding them if they should happen to think of trying again.

The villages and lineages of Kaiping took their defence into their own hands because the authorities were unable to safeguard people's property and lives. The diaolou played an important role. They served as a defence not only against the bandits throughout the xian, but also against any outsider, who might be the inhabitant of a neighbouring village or a member of a nearby lineage. The diaolou were typical products of traditional Chinese society, at a time of general public insecurity. They allowed the power and prestige of a village or lineage to be asserted and publicly displayed, so as to forestall any external provocation or attack. Just like the xiedou, they were signs of the isolationism of the Kaiping villagers. With the coming of Communist China in 1949, the establishment of a strong central power and an overall administrative system which even reached down to village levels and dismantled the lineage structures, the diaolou no longer served any purpose and were mostly abandoned ${ }^{63}$. Nowadays, it is extremely rare to find any that are inhabited. Those which have not been completely deserted are used to raise chickens or as storage barns for keeping implements, fertiliser, straw etc.

The emigrants' influence is visible in the buildings erected in the late nineteenth and early twentieth centuries in Kaiping, where the diaolou combine Chinese and Western features. Unlike the Western-style building in the foreign concessions in the large cities, the diaolou were built in the countryside, in villages and on the initiative of the peasants themselves. Contrary to normal expectations, thanks to emigration we can see a certain "cosmopolitanism" among the peasants in Kaiping, showing that it was not just the well-off educated classes in China who were open to Western influences. This is one way of thinking about the diaolou, and such views have gained credence since the open-door policy of 1979 and the consequent return to respectability of the overseas Chinese. After all, the diaolou are the epitome of overseas Chinese culture, embodied in stone. 


\section{ENDNOTES}

1. According to Ricci's Dictionary, diao means a "house made of stone", and diaolou is a military term which could be translated as a watchtower or fort with more than one storey (sheltering a small troop to guard a frontier).

2. According to interviews with Zhang Jianwen, a Kaiping official in charge of the municipal council office working to have the diaolou included on the Unesco list of world heritage sites. In early 2006, the council organised an exhibition in a hotel in the town and provided some figures to justify their bid. Before its inclusion on the list in 1997, the town of Pingyao (Shanxi) had an income from tourism amounting to 180,000 yuan; in 1998, this rose to 5 million yuan, and in 2000, to 10 million yuan. Another example was provided by the village of Xidi (Anhui), which was included on the list in 2000: in 2001, the sale of entry tickets alone brought in 11 million yuan. For the importance given to tourism, and the issues involved, see also Katiana Le Mentec, "The Three Gorges Dam Project-Religious Practices and Heritage Conservation", China Perspectives, No. 65, May-June 2006, pp. 2-13.

3. There are also some remaining diaolou in Taishan and Xinhui. The four xian, or siyi (sze yap in Cantonese) of Kaiping, Taishan, Xinhui and Enping belong to the same subculture. Sometimes a fifth xian, Heshan, is included.

4. Kaiping xianzhi, Beijing, Zhonghua shuju, 2002.

5. See, for example, Hua Linshan and Isabelle Thireau, Enquête sociologique sur la Chine, 1911-1949, Paris, PUF, 1996. This work deals with the xian of Taishan (adjoining Kaiping), as does Yuen-fong Woon's The Excluded Wife, Montreal, McGill-Queen's University Press, 1998. As the diaolou are part of the architecture of the qiaoxiang, photographs can be found in such works as Lynn Pan (ed.) The Encyclopedia of the Chinese Overseas, Richmond, Curzon Press, 1999.

6. Zhang Guoxiong, Kaiping diaolou, Guangzhou, Guangdong renmin chubanshe, 2005, $101 \mathrm{p}$. Some are mainly photographic collections, like Lao fangzi: Kaiping diaolou yu minju, Nanjing, Jiangsu meishu, chubanshe, 2002, or Zhang Jiangwen, Qian diao wangguo Kaiping (A Land of Diaolou-Kaiping City), Hong Kong, Hong Kong Yinhe Publishing House, 2002.

7. Kaiping qiaoxiang wenhua congshu bianweihui (ed.), Diaolou cangsang, Guangzhou, Huacheng chubanshe, 2001, $179 \mathrm{p}$.

8. Kaiping xianzhi, 2002, op. cit., Kaiping xianzhi 1932, Hong Kong, Minsheng yinshuju, 1933, 9 Vols., 45+2 juan. The local administration published official annals for the xian of Kaiping (Kaiping xianzhi) under the Empire in 1673, 1715 and 1823, under the Nationalists in 1932, and then under the PRC in 1958. 1909 also saw the publication of a Kaiping xiangtu zhi.

9. The highest point, Mount Tianlu, reaches 1,250 metres.

10. Kaiping xianzhi, 2002, p. 194.

11. It is thought that between the mid-seventeenth and mid-nineteenth centuries, the population of China tripled (from around 120-140 million to some 420 million).

12. Kaiping xianzhi, 2002, op. cit., p. 321.

13. For the clan structure based on lineage, see Hua Linshan and Isabelle Thireau, op. cit., pp. 5-12.

14. The principal clans, which might include up to 30,000 people at the beginning of the twentieth century, were the Zhang, the Guan, the Situ, the Tan, and the Zhou. 
15. Frederic Wakeman Jr., "Les sociétés secrètes du Guangdong 1800-1856" in Jean Chesneaux (ed.), Mouvements populaires et sociétés secrètes en Chine aux XlXe et XXe siècles, Paris, François Maspéro, 1970, pp. 90-116.

16. The Hakka (kejia) came from northern China to Guangdong during the Southern Sung (1127-1280) and Yuan dynasties. The Punti (bendi, "locals") also came from the north, reaching Guangdong before the Hakka.

17. Kaiping xianzhi, 1933, op.cit., juan 22 and juan 23. These data are also to be found in the 2002 edition of the monograph.

18. Kaiping xianzhi, 1933, op.cit., juan 44, p. 3. The Fengfulou appears to be the first diaolou mentioned in an official document.

19. At first it was called Yalonglou. Another diaolou was built by the Guan shortly before the Yalonglou in a village neighbouring Sanmen, and was destroyed in 1962: Diaolou cangsang, op. cit., pp. 157-159; Lao fangzi: Kaiping diaolou yu minju, op. cit., p. 8.

20. Kaiping xian wenwu zhi (Annals of the cultural heritage of the xian of Kaiping), Kaiping, Guangdong renmin chubanshe, 1989, 121-124.

21. Grey bricks are made in exactly the same way as red ones but, whereas the red ones are taken out of the kiln and left to cool slowly, grey bricks are doused with water in the kiln while still extremely hot: Lin Huicheng, Chuantong jianzhe shouce, Taipei, Yishujia chubanshe, 1989; Jiang Xiaoping, Zhongguo chuantong jianzhu yishu, Chongqing, Xinan shifan daxue chubanshe, 1989; Zhang Yuhuan, Zhongguo gu jianzhu baiwen, Beijing, Zhongguo dang'an chubanshe, 2000.

22. There are also diaolou built with two grey brick walls, an inner and an outer, with a layer of reinforced concrete between them.

23. The iron window sills and frames still exist, as do the bars on the windows and doors, except where the iron was melted down in the small rural furnaces during the Great Leap Forward.

24. Portland Cement was perfected in 1824 by a Briton, Joseph Aspdin. He patented his invention under the Portland trademark, which he considered good for advertising since, according to him, his material resembled a highly prized stone for building which came from the quarries on the Portland peninsula, or "Island", in Dorset.

25. Sometimes instead of gravel, pounded beach pebbles (eluanshi) were used, in which case the diaolou were built of hunningtu.

26. Wood was nevertheless sometimes used to save money.

27. There can be no doubt that more of the diaolou built of stone or brick were demolished than those made of reinforced concrete, since their materials could be reused, unlike reinforced concrete.

28. In the case of a qiaoxiang, the money from its emigrants represents at least a half of its resources, according to the definition provided by Lynn Pan (ed.), The Encyclopedia of the Chinese Overseas, Richmond, Curzon Press, 1999, p. 27.

29. Before the Second World War, between 8.5 and 9 million Chinese - largely from Guangdong and Fujian - are believed to have been living outside China, mostly in South-east Asia, ibid., pp. 27 and 58.

30. The same applies to the inhabitants of the neighbouring xian, Taishan, Xinhui, and Enping. About half of the Chinese who emigrated to the United States between 1911 and 1949 come from the siyi.

31. The Chinese for San Francisco is Jiujinshan, "Old Gold Mountain". The California gold rush was followed by the one in Australia (1851), and Canada (Fraser Valley, 1858). 
32. The Convention of Peking, on October $18^{\text {th }} 1860$, ended the Second Opium War (1856-1860) between the Anglo-French forces and China. Among other provisions, it allowed British ships to transport Chinese labourers to the Americas, where they were to replace the freed African slaves.

33. Kaiping xianzhi, 2002, pp. 3-4.

34. There were three ways of emigrating. In the first, which was rare, the emigrant paid for his own passage. The second means was that of contract or indentured migration (qiyue huagong, known popularly in Guangdong as the "piglets trade", mai zhuzai). It was through this system of indentured labour that coolies were recruited for the plantations of Southeast Asia or the Americas (Cuba, the British West Indies, Peru, etc.). The third way was through sponsoring: the emigrant's passage money was loaned in advance by a sponsor (who could be a kinsman)-usually a Chinese already living in the country of entry-and he repaid the loan with interest after his arrival. The main embarkation ports were Xiamen (Amoy), Macao, Hong Kong, Guangzhou, and Shantou (Swatow).

35. Chinese immigration to the United States was unrestricted from 1848 to 1882, after which a succession of laws forbade entry to new labourers, and prevented those already present from becoming citizens. Immigration to Canada was unrestricted from 1858 to 1884 , but after 1885 the same restrictions were applied, because there too railway construction had ended. In Australia, Chinese immigration was forbidden in 1901 and naturalisation in 1903. In all three countries, the laws on Chinese immigration were revised after the Second World War, during which the Chinese had fought on the allied side against the Japanese.

36. See Yuen-fong Woon, The Excluded Wife, op. cit., pp. 50-51, which deals largely with the xian of Taishan, adjacent to Kaiping. The husband was represented by a cockerel, as was customary when a young man betrothed as a child died before the marriage ceremony.

37. In the first half of the twentieth century, as Hua Linshan and Isabelle Thireau's study shows, emigration led to more than half the male children in the village of Ping'an, in the neighbouring xian of Taishan, being adopted (op. cit., pp. 26-28).

38. "The use of money earned by emigrants roused numerous controversies and caused family conflicts, because the emigrants often addressed the money orders to the head of the family, namely their father. The land and other assets bought with these contributions belonged nominally to the latter, and were then divided up among the sons, which also gave rise to contention. Similarly, the death of a close relative abroad, and the way his assets were dealt with by the other emigrant relatives, sometimes led to disputes", ibid. pp. 227-228.

39. According to Yuen-fong Woon, one emigrant out of every five or six returned to China with enough money to build a house and live in a "new village": Yuen-fong Woon, Social Organization in South China, 1911-1949: The Case of the Kuan Lineage in K'ai-p'ing County, Ann Arbor (Michigan), The University of Michigan Center for Chinese Studies, 1984, p. 141. According to other figures, $80 \%$ of the emigrants were impoverished, $15 \%$ managed to get by, and 5\% returned very rich. The latter became either merchants or landowners, ibidem. Other figures put the proportion of emigrants who came back rich at $10 \%$, ibid., p. 145.

40. Kaiping xianzhi, 1933, op. cit., juan 5, pp. 18-19.

41. Kaiping xianzhi, 1933, op. cit., juan 12, p. 6. 
42. The communal diaolou could turn out to be less secure than the family ones, as is shown by a theft worthy of Gaston Leroux's Mystère de la Chambre jaune, reported in the chronicle for 1937. A large sum of money was stolen without any sign of forced entry, either through the main entrance to the diaolou or through the door to the room containing the safe. The matter became widely known, because the victim put an advertisement in many newspapers and bulletins read by emigrants.

43. Usually made of Chinese pine.

44. The diaolou were built before 1949 , so their names are read from right to left.

45. Diaolou cansang, op. cit., pp. 151-153.

46. Diaolou cansang, op. cit., pp. 144-146.

47. The Japanese occupation of Hong Kong from December 1941 to August 1945 blocked off the remittances from abroad. This was a disaster for the area of the four xian and led to hundreds of thousands dying of starvation.

48. Zhang Guoxiong, Chikan guzhen, Shijiazhuang, Hebei jiaoyu chubanshe, 2004, p. 59.

49. Interview with Zhang Jianwen, who was in charge of getting the diaolou accepted as world heritage sites.

50. Lynn Pan (ed.), op. cit., p. 30.

51. Yi ge jiaoyin san ge zei.

52. Kaiping xianzhi, 1933, op. cit., juan 22, p. 1; Kaiping xianzhi, 2002, op. cit., p. 40; Diaolou cangsang, op. cit., pp. 20-22.

53. On November $9^{\text {th }} 1911$, twenty-eight pupils from the school in Lougang, near Changsha, were kidnapped and freed for a ransom of 30,000 yuan: Kaiping xianzhi, 1933, op. cit., juan 22, p. 3; Kaiping xianzhi, 2002, op. cit., p. 38 (this edition states that it happened in 1912 instead of 1911).

54. Diaolou cansang, op. cit., pp. 20-22.

55. One of the best known diaolou schools was the Baoshulou, in the village of Tanxi, near the township of Tangkou. It was built in 1921, in Byzantine style, and was fronted by a Xie ancestral temple: Zhang Jianwen, Qian diao wangguo Kaiping, op. cit., p. 12.

56. The xian monograph of 1932 identifies the seven major minjun and their places of operation, plus an organisation set up by the triad leaders in the town of Chikan.

57. The troops under Chen Jiongming (1878-1933) entered Guangdong from Zhangzhou in Fujian province. Two years later, Chen broke with Sun Yat-sen and drove him out of Guangzhou.

58. Kaiping xianzhi, 1933, op. cit., juan 23, p. 6.

59. Diaolou cansang, op. cit., pp. 6-7.

60. The Fang were willing to pay him "tea money" (chaqian). This normally means "a tip", but that would be to underestimate its size in this case.

61. See Lucien Bianco, Jacqueries et Révolution dans la Chine du XXe siècle, Paris, Editions de la Martinière, 2005, pp. 91-98 and pp. 321-350. The wide-ranging means employed in the xiedou of 1948 in Xinhui (a xian adjoining Kaiping, and one of the siyi), as reported on pages 332-333, can perhaps be explained in terms of monetary support from emigrants. See also Lucien Bianco, Peasants without the Party, Armonk, N.Y., London, M.E. Sharpe, 2001.

62. Nowadays, the rice is threshed out in the fields. A machine, whether driven by hand, pedals or a motor, turns a large drum onto which metal loops or teeth are attached. The sheaves are held by hand, so as to press the heads against the rotating drum and separate the grain. The chaff is left to dry in the sun and the rice grains are dried along the roadside or on the terraced roofs in the villages. 
63. The diaolou were still in use during the Sino-Japanese war. The villagers used them against the Japanese soldiers who, unlike the bandits, attacked by day. Even if certain penalties exacted by the Japanese army and their Chinese collaborators did indeed resemble those of the bandits, the fact that the peasants made this connection is very revealing about their mentality in those days. In the same period, some of the diaolou were used as strongholds by the Japanese troops and by the Nationalists. They were also used by the Chinese Communist party for clandestine meetings, for it was easy to keep a watch against unwelcome visits.

\section{ABSTRACTS}

Situated in western Guangdong province, the xian of Kaiping was one of the centres of Chinese emigration in the nineteenth and twentieth centuries. This article is concerned with the diaolou built there at the end of the Empire and in the early years of the Republic. These fortified buildings were built with money from emigrants, trying to protect their village at a time when public order was very uncertain. They are notable for their combination of Chinese and Western architectural features.

INDEX

Subjects: societe 